\title{
Scholarly communication education and training
}

A fter more than a decade of working in scholarly publishing from within a research library (at the University of Michigan), in the fall of 2013 I began teaching in the Graduate School of Information and Library Science at the University of Illinois. I arrived in my new faculty position, anxious to share my years of work experience.

As early immersion, I joined the team teaching a class required of all new graduate students in the program, Information Organization and Access. The course introduces students to many of the core principles of librarianship and encourages thinking about possible career paths. The instructors frequently shared job advertisements from throughout the library profession with students.

Owing to my own experience and inclinations and to trends in the academic library, I frequently posted positions for scholarly communication and publishing librarians. This excited me: "Look! Jobs in my area of specialization!" and made me anxious: "Are we teaching the kids what they need to know? Are we educating and training a new generation of professionals that can participate in the creation, as well as the curation, of the scholarly record? What do those professionals need to know?"

Scholarly communication competencies are increasingly called for at two levels in research libraries. First, many such libraries are creating specialist positions for expert practitioners who will lead in developing programs and services to support scholarly communication. Second, we are seeing a heightened expectation that librarians who support disciplinary scholarship are fluent in the language of scholarly communication and can address its opportunities and challenges. Scholarly communication literacy has become a core competency for academic librarians. We see a growing need for both experts and informed generalists. The role of specialists intersects with generalists to the extent that the specialist job responsibilities include educating their colleagues about the changes in scholarly communication and learning from those same colleagues, who bring a valuable frontline perspective to defining library programs and services that respond to those changes.

The recent ACRL report on "Intersections of Scholarly Communication and Information Literacy" ${ }^{1}$ calls out the way in which knowledge of scholarly communication issues is deeply entwined with other areas of research library work.

To get a sense of what scholarly communication skills academic libraries are

Maria Bonn is senior lecturer at the University of Illinois-Urbana Champaign's Graduate School, e-mail: mbonn@illinois.edu

Contact series editors Zach Coble, digital scholarship specialist at New York University, and Adrian Ho, director of digital scholarship at the University of Kentucky Libraries, atcrlnscholcomm@gmail.com with article ideas

(c) 2014 Maria Bonn 
currently seeking in their staff members, let's take a close look at some of those job postings I shared with my students this past semester. I'll focus on three such postings: one for a scholarly communication librarian at the University of Colorado-Boulder, one for a scholarly communication librarian at Princeton University, and one for a research/scholarship initiatives manager at the Center for Digital Research and Scholarship at Columbia University.

Among the responsibilities these positions share, we see management of many areas of institutional repositories: "Work closely with collection development and technical services to ensure that, as appropriate, licenses support [the institution's] Open Access Policy and its Institutional Repository"... "Develop and maintain the Institutional Repository website"... "Consult with and advise faculty on publishing agreements, and retention of right to deposit materials in the institutional repository"... "Oversee the institutional repository service"..."play a significant leadership role in implementing, managing, and promoting the University's institutional repository."

Although management of the institutional repository is an important part of many of these jobs, it is not the only need commonly expressed in these advertisements. The positions all emphasize the importance of education and advocacy: "The Scholarly Communications Librarian will manage...efforts to support scholarly publication innovations and reforms"... "provide campus-wide advocacy for Open Access to scholarly works and convey the University's vision of Open Access in various campus and national forums and publications"... "Advise faculty and serve as a library resource on copyright compliance issues related to Open Access"... "Conduct outreach to faculty and departments in collaboration with subject liaison librarians. Monitor national copyright and intellectual property trends and policy issues. Develop and implement an educational program to increase awareness in copyright, Open Access, and other scholarly communication issues" ... "This position advocates for new scholarly communication models"..."This position provides outreach and consultations on depositing content, publishing options, author rights, copyright, and Open Access"... "Serve as a resource on local and national policy to help the University community stay informed about and engaged with the changing landscape for scholarly communication"..."The program includes education, training."

Another theme in these advertisements is the call for flexibility, innovation, and keeping abreast of the many changes in scholarly communication. We see required qualifications such as "aptitude for thinking creatively and developing products and services" and "evidence of leadership, entrepreneurship, and initiative," and notes that the position holder "encourages experimentation and risk-taking in digital scholarship projects."

One posting calls directly for candidates who have "capacity to thrive in the fastpaced, future-oriented environment of a top research institution." Clearly academic libraries see scholarly communication as a dynamic and evolving area of work (as are many areas of librarianship: e.g., digital archives and data management) and are seeking staff members who operate comfortably in such an area.

By scanning these recent job postings and others like them, and through discussions with both scholars and the librarians who support them (and those who are both), it is easy to generate an inventory of skills and areas of expertise related to scholarly communication required by today's research libraries.

While the job advertisements call for unsurprising degrees (master's in library and information science and advanced disciplinary degrees) and the obligatory excellence in oral and written communication, we also see a desire for skills in a wide range of other areas. These include, 
but are not limited to:

- A detailed understanding of copyright law and its implications, both for guiding use (in research and teaching) and for advising on best practices in ownership and management of copyright.

- Knowing how to read an author contract and understanding its ramifications.

- Familiarity with standard and emerging modes of scholarly communication in print and digital and in a variety of media, both formal and social.

- Experience in or familiarity with formal publishing. The number of libraries engaged in formal publishing continues to grow. As one indication of this growth, we see that the newly launched Library Publishing Coalition, "an organization dedicated to advancing the emerging field of library publishing," launched with more than 50 committed academic libraries as paying members. A 2013 article in The Journal of Web Librarianship argues that "Digital Publishing From the Library" is "A New Core Competency." "Academic libraries now recognize the value of adding publishing expertise to their staff talent pools and look to hire individuals that can apply expertise in traditional publishing functions to innovative areas of library publishing.

- An understanding of the economies of scholarly communication: the financial costs of publishing, expenditures on acquisitions and collections (and the constraints on those expenditures), and the reputational/professional economy that plays an important role in the tenure and promotion process so integral to the research institution. In recent years this attention to reputation and visibility has led to a perceived need to understand and generate "altmetrics" — - ways of measuring impact and prominence, especially through digital channels.

- An understanding of the role of digital technology and networked communication in the disciplines. The shorthand for this has become "familiarity with e-science or digital humanities." Digital humanities has generated considerable interest in the past several years, both because the humanities disciplines are changing in response to technology and because that response lays bare many of the issues with which all scholars are dealing.

- An understanding of best practices in data management and curation. As data sets become as easy to share as text, they have come to constitute their own form of scholarly communication, with attendant needs and requirements that libraries are only beginning to understand. While libraries are hiring data managers to attend to the technical storage and delivery requirements for data, those libraries are also seeing an emerging call for support in publishing, distributing, and curating that data.

- Familiarity with challenges and opportunities of digital repositories-both disciplinary and institutional. Managing and maintaining such repositories calls for a range of expertise in generating and maintaining metadata, in recognizing standards in order to ensure long-term preservation, and in understanding copyright and permissions so as to make informed decisions about both acquisition and distribution.

For academic libraries looking to tool up to provide better support for scholarly communication in their research institutions, the needs appear many and the wish list long. There are many ways in which the library community can meet these needs, especially since these skills can be useful in other emerging areas of librarianship. Libraries can of course consider hiring dedicated scholarly communication librarians, a route, as we have seen in the job postings under consideration, that many research libraries are increasingly taking.

But there are other ways to build capacity as well: existing staff with interest in, and on-the-ground exposure to, issues in scholarly communication can expand their roles to address user demands, which might be particularly appropriate work for disciplinary specialists. In combination with or in addition to building upon existing strengths, 
staff already in place can pursue new training, through professional associations and through continuing academic education. Scholarly communication programming and services can also be built through campus collaborations. Libraries can find aligned partners in campus publishing efforts, such as university presses, in the general counsel's office and/or law schools, in media studies departments, in offices of research and, of course, in the scholars who populate their campuses and who are often keenly interested in the conditions under which they communicate and propagate their research findings.

Collaborations can also be built within the libraries themselves, by bringing together staff with expertise in a variety of areas into working groups or planning committees to define areas of need and to suggest and develop programming to meet such need.

All these strategies are viable, but it is also clear that we are at a moment in the library profession that calls for expansion of education and training to attend to the current climate and the needs of the academic community, an expansion that can and should be undertaken both by library and information schools and through professional development, both locally sponsored and conducted by our professional organizations.

It is important that librarians and the schools that train them not be daunted by this emerging area of activity and its accompanying large battery of required skills, many of which are increasingly called for throughout the profession. We should recognize that budding developers and supporters of a functional and sustainable scholarly communication environment need to know many of the things that librarians already know and in which librarians are deeply invested.

While there is certainly room for developing specific expertise in things like metadata, preservable publication formats, and methods for evaluating the quality and impact of scholarly publications, what is perhaps most urgently needed is a systemic awareness of the issues at stake for our scholars in making decisions about communicating the results of their work and a sensitivity to the ramifications of those decisions: the stakes for the scholars themselves, the institutions in which they work, the libraries that help make that work possible and, indeed, for the larger society which can progress and develop as a result of that work.

In this light, the first step in tooling up is to expand the professional conversations about our means of scholarly communication and their implications: among ourselves (librarians) and with our scholars.

\section{Notes}

1. "Intersections of Scholarly Communication and Information Literacy: Creating Strategic Collaborations for a Changing Academic Environment," a white paper published by ACRL, http://acrl.ala.org /intersections/.

2. http://www.librarypublishing.org/.

3. Julie Lefevrea and Terence K. Huwe DOI: 10.1080/19322909.2013.780519.

4. See, for example, http://altmetrics.org /manifesto/.

\section{Virtually Embedded: The Librarian in an Online Environment}

ACRL announces the publication of Virtually Embedded:The Librarian in an Online Environment, edited by Elizabeth Leonard and Erin McCaffrey. This casebook, a blueprint for embedding academic librarians in online environments from undergraduate to science-based graduate schools to MOOCs, is the first to extensively explore how librarians can play a key role in the virtual academic landscape.

Virtually Embedded: The Librarian in an Online Environment is available for purchase in print, as an e-book, and as a print/ebook bundle through the ALA Online Store; in print and for Kindle throughAmazon.com; and by telephone order at (866) 746-7252 in the United States or (770) $442-8633$ for international customers. 